\title{
Electrochemical Detection of Hydrazine Based on Facial Synthesized Sulfur-Poly(Pyrrole-Co-Aniline) Nano-Fiber
}

\author{
Hui Peng ${ }^{1, *}$ and Chunyan Liang $^{2}$ \\ ${ }^{1}$ School of Materials Science and Engineering, Beijing Institute of Technology, Beijing, 100081, \\ People's Republic of China \\ ${ }^{2}$ College of Computer Science and Technology, Shandong University of Technology, Shandong Zibo, \\ 255049, People's Republic of China \\ *E-mail: cyl_bit@yahoo.com
}

doi: $10.20964 / 2016.10 .48$

Received: 15 July 2016 / Accepted: 18 August 2016 / Published: 6 September 2016

Chemical oxidation method was explored to prepare the poly(pyrrole-co-aniline) (PPyA) copolymer. Cetyltrimethyl ammonium chloride (CTAC) was used as the template in the oxidation reaction. Then the S/PPyA composite (nano-sulfur/poly(pyrrole-co-aniline)) was obtained by treating the mixture of sublimed sulfur and PPyA at $160{ }^{\circ} \mathrm{C}$ for $24 \mathrm{~h}$. The as-prepared PPyA and S/PPyA were characterized by various techniques including X-ray powder diffraction (XRD), scanning electron microscopy (SEM), Raman spectroscopy and Fourier transform infrared spectroscopy (FTIR). The S/PPyA was used to modify the glassy carbon electrode (GCE) and the electrochemical activity of as-synthesized $\mathrm{S} / \mathrm{PPyA} / \mathrm{GCE}$ for the oxidation of hydrazine was investigated. The low detection limit of $0.18 \mu \mathrm{M}$ $(\mathrm{S} / \mathrm{N}=3)$ and fast response time within $3 \mathrm{~s}$ were achieved. The remarkable performance makes S/PPyA/GCE a promising electrode applied in the construction of sensors for the determination of hydrazine.

Keywords: Poly(pyrrole-co-aniline); Sensor; Electrochemistry; Hydrazine; Composite

\section{FULL TEXT}

(C) 2016 The Authors. Published by ESG (www.electrochemsci.org). This article is an open access article distributed under the terms and conditions of the Creative Commons Attribution license (http://creativecommons.org/licenses/by/4.0/). 